\title{
Specialized Accreditation and Academic Libraries
}

\section{Stuart Frazer}

Literature on academic libraries and the accrediting process has centered on regional accrediting agencies. Library guidelines from seventeen specialized accrediting bodies were evaluated and compared to guidelines from regional accreditors. Like the regional accrediting agencies, most specialized accrediting agencies stress input or process measures over output measures. A few specialized accreditors were found to be more prescriptive than the regional accreditors in their demands for collection inputs, particularly journal holdings. An overview of specific characteristics of the specialized accrediting process is offered, along with suggestions for improving the library's participation in the process.

lthough specialized or professional program accreditation has been present in higher education for most of the century, recent events have intensified interest in the costs and benefits of this particular kind of academic review process. Proliferating accrediting bodies, rising costs, and stagnant or declining higher education funding have combined to make specialized accreditation a controversial topic on many campuses around the country. ${ }^{1}$ Because funding for public colleges and universities will likely continue to be problematic, and schools will continue the struggle to retrench, specialized accreditation may become an even more contentious issue over the next few years. Competition for scarce institutional resources may escalate interdepartmental conflict in academia. Specialized accreditation at times may be an important variable in these conflicts.

Specialized program accreditation issues are crucial to academic library administration. Usually libraries must generate self-study reports to be used in the accreditor's library evaluation.
Moreover, academic libraries are sometimes influenced to set service priorities based on an institution's specialized accreditation agenda. American Chemical Society journal requirements, for example, may impose a strain on the financial resources of a small college library, affecting the overall adequacy of library services. Despite the importance and role of accreditation in higher education, much confusion exists about the process. ${ }^{2}$ Further, librarians may have to face the challenges accreditation brings with little background in the subject.

\section{OVERVIEW OF THE PROCESS}

Accreditation has been defined as:

... a voluntary process conducted by peers via nongovernmental agencies to accomplish at least two things-to attempt on a periodic basis to hold one another accountable to achieve stated, appropriate institutional or program goals; and to assess the extent to which the institution or program meets established standards. ${ }^{3}$

Typically, two types of accreditation are recognized. Institutional accredita-

Stuart Frazer is Reference Librarian at West Virginia State College, Institute, West Virginia 25112. The author would like to thank Dr. Kerry Kilburn for her input into this article. 
tion, usually carried out by one of six regional accrediting organizations, reviews entire institutions. ${ }^{4}$ Specialized or professional accreditation reviews individual programs within an institution. Although the organizations conducting institutional or specialized accreditation are nongovernmental, federal financial aid eligibility is often tied to the requirement that an institution or program be accredited. ${ }^{5}$ In some cases participation in a degree program accredited by a specialized accreditation organization is a legal prerequisite for eligibility to take a professional licensing or certification test. ${ }^{6}$ Because it has been the focus of recent higher education controversy and presents unique challenges to academic library administrators, specialized accreditation is the focus of this paper.

Efforts by professional organizations to monitor and influence professional training in the modern sense are usually traced back to the turn of the century. Medicine and law led the way, but a variety of other professions had followed by the 1920s. ${ }^{7}$ By 1991, seventy-three specialized accrediting groups were recognized by either the United States Department of Education or the Council on Postsecondary Accreditation (COPA), a private nonprofit corporation serving as an "umbrella" group for the various independent accrediting agencies. ${ }^{8}$

Efforts by professional organizations to monitor and influence professional training in the modern sense are usually traced back to the turn of the century.

COPA maintains stringent standards for recognition of new accrediting bodies, and membership is voluntary on the part of the aspiring accrediting organization. Various groups engage in specialized accreditation without benefit of COPA sanctioning. ${ }^{9}$ Although COPA has taken the problem of proliferating accrediting groups seriously, it lacks the authority to maintain control over all groups who may wish, for whatever rea- son, to engage in specialized accreditation activities. ${ }^{10}$ At the time of this writing indications are that the six regional accreditors may leave COPA to form their own organization. A subsequent collapse of COPA could lead to even greater proliferation of specialized accreditors. ${ }^{11}$ [Note: COPA disbanded in December 1993.]

The specialized accreditation review process begins with an institution's decision to seek or continue having a particular program accredited by the appropriate organization. A detailed self-study is produced by the department or program seeking accreditation. The self-study is submitted to the accrediting body, which then initiates a site visit conducted by a team of peers. During this visit the peer team examines the program in light of the self-study and the accrediting body's standards. The academic library is usually included in both the self-study and the site visit. The site visit team prepares a report which is submitted to both the accrediting body and the program seeking accreditation. Members of the program seeking accreditation next submit a formal response to the site visit team's report, after which the accrediting body makes a determination regarding accreditation status for the program. ${ }^{12}$

\section{ACADEMIC LIBRARIES AND SPECIALIZED ACCREDITATION}

The literature on academic libraries and accreditation has concentrated primarily on regional accreditation. Much of the recent work focuses on the selfstudy process as a mechanism for planning and change. ${ }^{13}$ Little attempt has been made to differentiate between the two types of accreditation or to discuss the unique challenges specialized accreditation can bring to the academic library.

Although accreditation has not been a high profile subject in the library literature, some conclusions can be drawn from the work which has been done. Recent studies of regional accreditation standards indicate a heavy concentration on input or process measures, rather than output measures. ${ }^{14}$ Examples of 
input measures include staff, money, materials, and facilities. ${ }^{15}$ Evaluation of access, cooperative agreements, and planning/organizing would be defined as process measures. ${ }^{16}$ Output measures would concentrate on "the effect of library service on its public." ${ }^{17}$ An emphasis on collection size, facilities, staffing, and networking or cooperative agreements can be expected from accreditors. ${ }^{18}$ There is general agreement that measures of library use are not emphasized in regional accreditation. $^{19}$ Moreover, regional accrediting bodies do not make use of standards for academic libraries developed by the Association of College and Research Libraries. ${ }^{20}$ Casserly's work suggests that better guidelines for evaluation, from ACRL or other sources, are needed to carry out effective self-studies. ${ }^{21}$

To explore whether specialized accrediting group library guidelines share the same characteristics as their regional counterparts, a study was made of the content of guidelines from seventeen specialized accreditors (see appendix A). The seventeen groups were selected to include a variety of agencies active on a large number of campuses around the country. Most of these groups share the tendency of regional accrediting organizations to stress vague input measures although groups vary in the inputs mentioned and their levels of specificity. Table 1 provides a summary of guideline content based on ten content analysis categories used in Kania's study of regional accrediting agencies. ${ }^{22}$

Of seventeen specialized accrediting bodies examined, fifteen included criteria stipulating "adequate" or "sufficient" library resources. Typical of these criteria are the National Council for Accreditation of Teacher Education (NCATE) requirement that "Library holdings provide adequate scope, breadth, and currency to support the professional education programs" and the Joint Review Committee on Educational Programs in Nuclear Medicine Technology's assertion that "Students shall have ready access in time and location to an adequate supply of current books, journals,
TABLE 1

FREQUENCY OF TOPICS

APPEARING IN SPECIALIZED ACCREDITATION LIBRARY GUIDELINES $(N=17)$

\begin{tabular}{lc}
\hline Topic & $\begin{array}{c}\text { No. of Groups } \\
\text { Including }\end{array}$ \\
\hline Collection & 15 \\
Access & 12 \\
Cooperative agreements & 9 \\
Faculty participation & 8 \\
Budget/funding & 7 \\
Facilities & 7 \\
Staff & 6 \\
Hours & 5 \\
Use & 5 \\
Administrative position & 2 \\
Planning & 1 \\
\hline
\end{tabular}

periodicals, and other reference materials related to the curriculum." ${ }^{23}$

In only one case studied are collectionrelated guidelines explicitly tied to a recognized set of library standards. The National Architectural Accrediting Board states that the library's collection should be compared to the "comprehensive, research, study, basic, and minimal levels defined by the American Library Association in Guidelines for Collection Development." ${ }^{24}$ That same group also suggests the use of "ACRL Guidelines for Branch Libraries." 25

The American Chemical Society (ACS) and the Council on Social Work Education are more concrete than the other groups in their library collection requirements. Both focus heavily on journal collections and include lists of desired journal holdings. The American Chemical Society, which is not a member of COPA, is by far the most prescriptive of any of the specialized accrediting bodies examined. Their library guidelines state: "At minimum, all collections must have hard-copy subscriptions to 14 current journals from the CPT [Committee on Professional Training] list. ..." ${ }^{26}$ Examination of the CPT list shows that the absolute minimum cost a library would 
have to incur to meet ACS journal standards would be $\$ 5,245$ per year, based on prices from the 1992-93 Faxon catalog. In addition, the library is required to offer access to Chemical Abstracts, either hard copy or online. The Council on Social Work Education includes a work sheet on library journal holdings designed to ascertain how many titles indexed in Social Work Research and Abstracts are available in the library. They do not specify a minimum number of journals required and acknowledge, "It is not expected that every program will have every journal. ..."27

Statements about "access" to collection resources are included in the guidelines for twelve of seventeen accrediting groups examined, although "access" is never adequately defined. Other frequently included criteria are the existence of cooperative/ILLagreements and faculty participation in collection development decision making. Less frequently included are guidelines for budget, physical facilities, staffing, hours, library usage, administrative position/governance structure, or evidence of planning.

Library use, the only real output measure mentioned, is considered an important criterion by five of the specialized accrediting agencies examined. The Accreditation Board for Engineering \& Technology points out: "The ultimate test of the library is the use made of it by the students, faculty, and institutional staff." ${ }^{28}$ The Accrediting Council on Education in Journalism and Mass Communication requests evidence of "Utilization of current periodicals by students in keeping abreast of the field." ${ }^{29}$ None of the groups mentioning library use suggests appropriate methods for assessing it.

Only six agencies mention library staffing. This reflects the view that libraries are composed primarily of monographs and journals rather than "human" resources. Exceptions to this position include the National Association of Schools of Music's statement: "Institutions are encouraged to engage specialized personnel," and the National Architectural Accrediting Board's query "Does the architecture library have suffi- cient professional librarians with a master's in library or information science and subject expertise in architecture or closely related fields?" ${ }^{30}$ For the most part, staffing is given a low priority.

\section{DISCUSSION}

Specialized accreditation, as with all assessment techniques, should be an authentic, good faith process designed to study and improve program quality. Librarians must, however, be aware that the political character of the process makes it ripe for misuse and abuse. ${ }^{31}$ Specialized accreditation's fundamental focus on the ability of particular academic programs to meet the standards of a professional association or advocacy group may provoke criticism that the institution is subsidizing a given discipline at the expense of other academic programs. Academic departments or divisions may attempt to use reports or standards provided by accrediting agencies as leverage to argue for an increased share of institutional funds, perhaps including a higher percentage of the library's materials budget. An institution as a whole may try to use specialized accreditation as an advertising tool to demonstrate the quality of the institution.

Critics have attacked the review process on a number of fronts. ${ }^{32}$ Perhaps the most basic criticism is simply the cost of the self-study process and the site visit, both of which the program or institution seeking specialized accreditation must pay. Institutions seeking specialized accreditation in several program areas may devote thousands of hours of faculty, staff, and administrative labor to creation of self-study reports. ${ }^{33}$ Institutional administrators may not be aware, moreover, that accreditation by particular specialized agencies may require significant channeling of library resources into a subject area on a permanent basis. At some institutions this may have a negative impact on the ability of the library to serve the entire college or university community.

As Antoinette M. Kania found for regional accreditation, the emphasis in specialized accreditation is on input or process guidelines. ${ }^{34}$ Although accredit- 
ing bodies have incorporated methods designed to emphasize assessment of educational outcomes, recent work suggests that, in practice, progress in this area has been slow. Much of specialized accreditation review still revolves around standards for "budgets, teaching loads, facilities, and organizational questions." 35 Sarah M. Dinham and Linda M. Evans conclude that "professional schools cannot claim that accreditation provides the integrated view of student experiences and outcomes that a comprehensive assessment requires." ${ }^{16}$ The findings presented here certainly show that progress toward an emphasis on outcomes in library evaluation is slow as well.

Although the general characteristics of library evaluation by specialized accreditors are similar to those of regional accreditors, specialized accreditation poses special challenges for academic libraries. Some specialized accrediting groups are more prescriptive in their demands for collection inputs than are the regional accreditors. This enables librarians to assess and forecast the costs of supporting an accredited program. However, while librarians may support increased use of professional standards in library evaluation, critics of specialized accreditation still cite the use of rigid standards as reason to reject the process. $^{37}$ Prescriptive standards may raise very difficult questions about equity in resource allocation. Librarians must think critically about how specialized accreditation by groups like the ACS influences the distribution of funds in support of academic programs. Vague library guidelines, like those in use by regional accreditors and most of this sample of specialized accreditors, offer the advantage of easy manipulation, though they may not contribute to the overall success of the accreditation process. What is really needed are evaluative guidelines that take into account the variety and complexity of library services. A variety of evaluative methods are already formulated and in use by librarians. However, most accreditors are either not aware of them or choose not to use them. George M. Bailey's work, based on comments solicited from forty academic librarians, suggests that "ACRL standards ... are still considered unrealistic by the ... accrediting associations." ${ }^{38}$

\section{What is really needed are evaluative guidelines that take into account the variety and complexity of library services.}

Decisions about seeking accreditation will not always be based entirely on genuine efforts to improve program quality but instead may stem from efforts by individual departments to gain advantages over other departments. Librarians also use accreditation reports and guidelines in support of their own agendas. Not all academic or professional disciplines, however, have relevant accrediting agencies. Clearly, academic departments without access to accrediting bodies may find themselves at a serious disadvantage when trying to compete for increasingly scarce resources. This may contribute to the proliferation of specialized accreditors, as practitioners and educators in a discipline argue that more accrediting bodies are necessary to ensure an equal institutional playing field.

The accreditation process can be used to benefit the institution and the library. Librarians need to be advocates for the proper use of accreditation as a tool to improve program quality. This requires knowledge of the accrediting process, the characteristics of particular accrediting agencies, and of campus politics. Moreover, librarians must be knowledgeable about how the process is sometimes misused. If specialized accreditation continues to be a contentious issue in higher education, inevitably librarians must prepare to be drawn into the fray. 


\section{REFERENCES AND NOTES}

1. Courtney Leatherman, "Specialized Accrediting Agencies Challenged by Campus Officials," Chronicle of Higher Education, Sept. 18, 1991, A1, A22-A23; Julie L. Nicklin, "Teacher-Education Programs Debate the Need for Accrediting Agency's Stamp of Approval," Chronicle of Higher Education, May 6, 1992, A19, A22; Courtney Leatherman, "Madison Shuns Journalism Accrediting, Stirring a Curriculum Debate," Chronicle of Higher Education, Dec. 18, 1991, A19.

2. H. R. Kells, Self-Study Processes: A Guide for Postsecondary Institutions, 2d ed. (Washington, D.C.: American Council on Education and Macmillan, 1983), 9.

3. Kells, Self-Study Processes: A Guide for Postsecondary Institutions, 10.

4. Middle States Association of Colleges and Schools; New England Association of Schools and Colleges; North Central Association of Colleges and Schools; Northwest Association of Schools and Colleges; Southern Association of Colleges and Schools; Western Association of Schools and Colleges.

5. Fred F. Harcleroad, "Accreditation: Voluntary Enterprise," in Understanding Accreditation, ed. Kenneth E. Young, Charles M. Chambers, and H. R. Kells (San Francisco, Calif.: Jossey-Bass, 1983), 50.

6. Kenneth E. Young, "Epilogue: The Future of Accreditation," in Understanding Accreditation, 394.

7. Robert Glidden, "Specialized Accreditation," in Understanding Accreditation, 188-90.

8. Leatherman, "Specialized Accrediting Agencies Challenged by Campus Officials," A23.

9. Ibid., A22.

10. Charles M. Chambers, "Council on Postsecondary Accreditation," in Understanding Accreditation, 302-3.

11. Courtney Leatherman, "Six Regional Groups Say They'll Drop Out of Council on Postsecondary Accreditation," Chronicle of Higher Education, Feb. 10, 1993: A15-A16.

12. Kells, Self-Study Process: A Guide for Postsecondary Institutions, 11.

13. Mary F. Casserly, "Accreditation-Related Self-Study as a Planned Change Process: Factors Relating to Its Success in Academic Libraries," Journal of Library Administration 8 (Spring 1987): 85-105; Delmus E. Williams, "Accreditation and the Process of Change in Academic Libraries," Advances in Library Administration and Organization 7 (1988): 161-207.

14. Mary F. Casserly, "Academic Library Regional Accreditation," College \& Research Libraries 47 (Jan. 1986): 46; James F. Bemis, "Conclusion of ACRL/COPA Institute on Libraries and Accreditation in Institutions of Higher Education," in Libraries and Accreditation in Institutions of Higher Education, ed. Julie Carroll Virgo and David Alan Yuro, (Chicago: Association of College and Research Libraries, ALA, 1981), 85.

15. Rosemary R. DuMont, "A Conceptual Basis for Library Effectiveness," College \& Research Libraries 41 (Mar. 1980): 103; Antoinette M. Kania, "Academic Library Standards and Performance Measures," College \& Research Libraries 49 (Jan. 1988): 19.

16. Casserly, "Academic Library Regional Accreditation," 41; Kania, "Academic Library Standards and Performance Measures," 19.

17. DuMont, "A Conceptual Basis for Library Effectiveness," 103.

18. Kania, "Academic Library Standards and Performance Measures," 19.

19. Bemis, "Conclusion of ACRL/COPA Institute on Libraries and Accreditation in Institutions of Higher Education," 85.

20. Kania, "Academic Library Standards and Performance Measures," 17; Casserly, "Academic Library Regional Accreditation," 46; George M. Bailey, "Evaluation of Libraries in the Accrediting Process-From the Standpoint of the Library," in Libraries and Accreditation in Institutions of Higher Education, 58-61.

21. Casserly, "Academic Library Regional Accreditation," 46; Jay Lucker, "Improving the Accreditation Process-A Librarian's Perspective," in Libraries and Accreditation in Institutions of Higher Education, 78; Bemis, "Conclusion of ACRL/COPA Institute on Libraries and Accreditation in Institutions of Higher Education," 86.

22. Kania, "Academic Library Standards and Performance Measures," 18.

23. Standards, Procedures, and Policies for the Accreditation of Professional Education Units (Washington, D.C.: National Council for Accreditation of Teacher Education, 1992), 60; 
Essentials and Guidelines for an Accredited Educational Program for the Nuclear Medicine Technologist (Salt Lake City, Utah: Joint Review Committee on Educational Programs in Nuclear Medical Technology, 1991), 6.

24. Conditions and Procedures (Washington, D.C.: National Architectural Accrediting Board, 1991), 64.

25. Conditions and Procedures (Washington, D.C.: National Architectural Accrediting Board, 1991), 63.

26. Library Guidelines for ACS Approved Schools (Washington, D.C.: American Chemical Society, 1992).

27. Handbook of Accreditation Standards and Procedures (Alexandria, Va.: Council on Social Work Education, 1991), app. 6, vii.

28. Criteria for Accrediting Engineering-Related Programs (New York: Related Accreditation Commission, Accreditation Board for Engineering \& Technology, 1991), 7.

29. Accredited Journalism and Mass Communications Education 1991-92 (Lawrence, Kans.: Accrediting Council on Education in Journalism and Mass Communications, 1991), 13.

30. Handbook 1991-92 (Reston, Va.: National Association of Schools of Music, 1991), 47; Conditions and Procedures, 66.

31. Louis W. Bender, "Accreditation: Misuses and Misconceptions," in Understanding Accreditation, 71-85.

32. Kenneth E. Young, "Prologue: The Changing Scope of Accreditation," in Understanding Accreditation, 13-15; Carnegie Foundation for the Advancement of Teaching, The Control of the Campus (Washington, D.C.: Carnegie Foundation for the Advancement of Teaching, 1982), 76-79.

33. Arthur Doerr, "Accreditation-Academic Boon or Bane," Contemporary Education 55 (Fall 1983): 6-8.

34. Kania, "Academic Library Standards and Performance Measures," 19.

35. Glidden, "Specialized Accreditation," 199.

36. Sarah M. Dinham and Linda M. Evans, "Assessment and Accreditation in Professional Schools," Review of Higher Education 14 (Winter 1991): 233.

37. Leatherman, "Specialized Accrediting Agencies Challenged by Campus Officials," A1.

38. Bailey, "Evaluation of Libraries in the Accrediting Process-From the Standpoint of the Library," 59.

\section{APPENDIX A \\ ACCREDITING ORGANIZATIONS EXAMINED}

Accreditation Board for Engineering \& Technology: Engineering

Accreditation Commission Accreditation Board for Engineering \& Technology: Related

Accreditation Commission

Accreditation Board for Engineering \& Technology: Technology Accreditation Commission

Accrediting Council on Education in Journalism and Mass Communications

American Assembly of Collegiate Schools of Business

American Chemical Society

American Dietetic Association

Council on Education for Public Health

Council on Social Work Education

Joint Review Committee on Education in Radiologic Technology (guidelines for both Radiographer and Radiation Therapy Technologist programs)

Joint Review Committee on Educational Programs in Nuclear Medicine Technology

National Architectural Accrediting Board

National Association of Schools of Music

National Association of Schools of Public Affairs and Administration

National Council for Accreditation of Teacher Education

National Recreation and Park Association 


\section{$A N N O \cup N C \mid N G$}

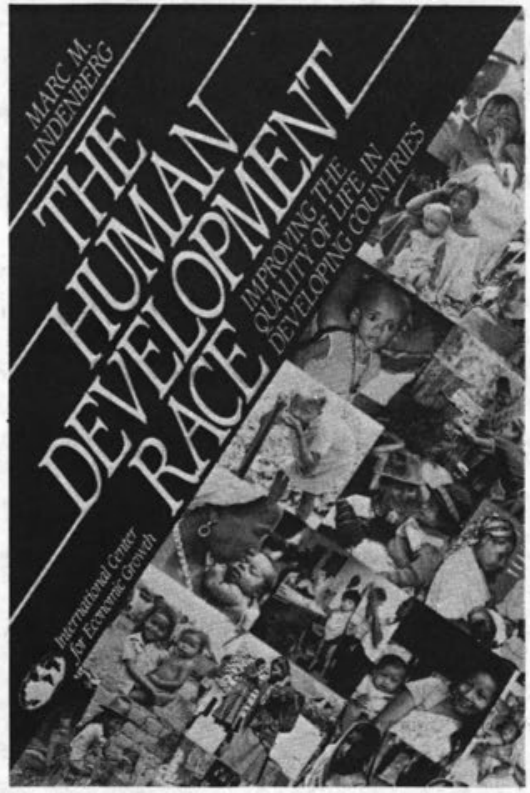

The Human Development Race explains why some developing countries have readily succeeded at improving the health, education, and income of their citizens while others seem mired in failure. After examining economic and social factors in the performance of ninety countries, Lindenberg focuses on the experiences of six Central American countries, furnishing wide-ranging, and sometimes surprising, conclusions.

Marc M. Lindenberg is currently senior vice president of programs for CARE, on leave of absence from his position as a public policy lecturer at Harvard's John F. Kennedy School of Government.

1993, 233 pages, Cloth ISBN 1-55815-277-6, \$29.95 Paper ISBN 155815-278-4, \$14.95

PUBLISHED BY ILC PRESS

"The Human Development Race combines human resource issues and quality of life issues in a creative fusion that allows a richer analysis than the usual economic approach. Lindenberg successfully tackles the thorny problems of measuring improvements in a practical and theoretically compelling way."

$$
\begin{array}{r}
\text { - William Ascher } \\
\text { Professor, Sanford Institute of Public Policy } \\
\text { Duke University }
\end{array}
$$

Order with MC or VISA: $(800) 326-0263$ in the United States (415) 981-5353 outside the United States Fax: (415) 986-4878 